\title{
An Error Analysis in Writing Discussion Text
}

\author{
Nesi Rahayu Utami, Sujoko, Dewi Rochsantiningsih
}

\author{
English Education Department \\ Teacher Training and Education Faculty \\ Sebelas Maret University of Surakarta
}

Email: rahayu.nesa@gmail.com

\begin{abstract}
This study is intended to find out 1) the types of errors made by the students, 2) the percentage of errors made by students, 3) the cause of errors, 4) strategies to overcome the difficulties. The study focuses on the description of error analysis based on surface category. The findings show that 1) the percentage of each kind of errors based on surface category: omission $36.48 \%$, addition $11.44 \%$, misformation $20.06 \%$, and misordering $32.01 \%$; 2) types of error made by the students are omission, addition, misformation, and misordering; 3) there are three cause of errors: interlingual transfer, intralingual transfer (overgeneralization, ignorance of rule restriction, incomplete application of rule, and semantic errors); 4) there are twelve difficulties and fifteen strategies to overcome the students ${ }^{\text {ee }}$ difficulties in writing discussion text.
\end{abstract}

Keywords: error analysis, discussion text

\section{INTRODUCTION}

Since there are some mistakes and errors made by learner in their writing task, an analysis is needed to analyze mistakes and errors, it is called error analysis. Richards and Renandya (2002: 303) stated there is no doubt that writing is the most difficult skill for L2 leaners to master. In writing, writers - especially L2 writers have to pay attention to higher level skills of planning and organizing as well as lower level skills of spelling, punctuation, word choice and so on. It can be concluded that writing is a complex activity involving higher and lower level skill of planning generate ideas and organize them.

Husain (2013:832) stated the nature of L1 writing is quite different from L2 writing. In L1 writing the learners can perform with least hesitation and with few possibilities of errors and mistakes but L2 writing is difficult. L2 learners of English foreign language are reluctant to write. In fact, the learners of English as a foreign language are faced with many social challenges while writing. Second language proficiency in L2 writing is usually defined as control over the mechanical elements and grammatical aspects of the target language.

Richards (1984: 189) says second language learners ${ }^{e e}$ errors are potentially important for the understanding of the processes of second language acquisition, and consequently the planning course incorporating the psychology of the second language learning. Besides, Ellis (1994: 51) stated error can be identified as a deviation from the norms of the target language.

It is important to know the differences between mistakes and errors in order to analyze the learner's errors. According to Dulay (1982: 139) a mistake refers to a performance error that is either a random guess or "slip", in that it is failure to utilize a known system correctly. All people make mistakes, in both native and second 
language situation. Native speakers are normally capable of recognizing and correcting such "lapses" or mistakes, which are not the result of a deficiency in competence but the result of some temporary break down or imperfection in the process of producing speech (Brown, 2004:217). Moreover, Brown (1994: 164) stated learning involves a process in which success comes by profiting from mistakes, by using mistakes to obtain feed back to make new attempts which successively more closely approximate desired goals.

It is normal for second language learners to make mistake. While an error is caused by the learners which are they are incompetence and usually unable to recognize their errors or to correct them. They do not understand the linguistics system of the language. They do not understand the linguistics system of the language. Daarus (2009: 486) stated mistakes is a natural process of learning and must be considered as part of cognition.

Brown (1994: 166) stated error analysis is the study of studentes errors which can be observed, analyzed, and classified the deviation to reveal something of the system operating within learners. Moreover, Richards (1984: 96) stated error analysis is the study of errors made by the second and foreign language learners. Error analysis may be carried out in order to (a) find out how well someone knows a language, (b) find out how a person learns a language, and (c) obtain information on common difficulties in language learning as an aid in teaching or in the preparation of teaching materials. Moreover, Endorgan (2005) stated error analysis deals with the learners" performance in terms of the cognitive processes they make use of in recognizing or coding the input they receive from the target language. Therefore, a primary focus of error analysis is on the evidence that learners"e errors provide with an understanding of the underlying process of second language acquisition.

Zahwahreh (2012) stated there is a kind of agreement that errors are significant in three different ways: First, they tell the teacher when he undertakes a systematic analysis how far toward the goals the learner have progressed and what remains for him to learn. Second, they give researchers evidences of how language is learned and what strategies and procedures the learners are employing in their discovery language. Third, they are unavoidable to the learner uses in order to learn. In other words, it is a way of testing the learners "e hypotheses about the nature of the language they are learning.

According to Dulay, Burt, and Krashen (1982: 146) the most useful and commonly used as bases for descriptive classification of errors are: (1) linguistic category: linguistic category classify errors according to either or both the language component or linguistic constituent. Language components include phonology (pronunciation), syntax and morphology (grammar), semantic and lexicon (meaning and vocabulary), and discourse while constituents include the elements that comprise each language component. (2) Surface category includes errors of omission, addition, misformation, and misordering. (3) Comparative taxonomy: the classification of errors in comparative taxonomies is based on comparison between the structure of second language error and certain other types of construction. There are three types of errors a) developmental errors; b) intelingual errors; and c) ambiguous errors. (4) Communicative effect taxonomies: communicative effect deals with errors from the perspective of their 
effect on the listeners or readers. It focuses on distinguishing between error and mistake that cause miscommunication.

There are several sources of error made by the learner in learning foreign language. According to Brown (1994: 213215) there are three factors that cause errors in learning a second language, they are: (1) interlingual transfer, the beginning stage of learning a second language is characterized by a good deal of interlingual transfer from the native language or interference (Brown, 1994: 213). (2) Intralingual transfer, the negative transfer of items within the target languge,or, in another way the incorrect generalization of rules within the target language (Brown 1994: 214). Besides, Richards (1984, 47-54) distinguishes intralingual errors into four types: a) overgeneralization; b) ignorance of rule restriction; c) incomplete application of rules; d) semantic error. (3) Communication strategies, the conscious employment or verbal or nonverbal mechanisms for communicating an idea when precise linguistics forms are readily available to the learner at a point in communication (Brown, 1994: 178).

From the explanation above, the objective of the study are (1) to describe the types of errors made by the students in constructing discussion text. (2) To find out the highest error frequency students made in constructing discussion text. (3) To describe the factors influencing the studentse error in constructing discussion text. (4) To provide suggestions, recommendations, and guidelines to help the students to avoid the errors in constructing discussion text.

\section{RESEARCH METHOD}

This study was designed primarily to serve the writeres ${ }^{\text {es }}$ purpose to describe the error analysis in writing discussion text made by the twelfth grade students. Based on the purpose of study, the writer used descriptive method. According to Fraenkel and Wallen (2000: 12) descriptive studies describe a given state of affairs as fully and carefully as possible. The obtained data in this study was collected from the teacher. The data were taken from 31 students.

After the data collected, the data were analyzed to get the conclusion. In this study, the data was analyzed by following the procedure: 1) identifying errors; 2) classifying errors on each type; 3) explaining errors; and 4) evaluating errors. The formulation that is used to analyze the percentage correction technique by using formula as follows:

The formula above means, the errors percentage can be computed by means the number of errors divided by the total number of errors, then multiplied by $100 \%$.

\section{RESEARCH FINDINGS AND DISCUSSION}

The data were collected through writing where each student had to make a discussion text. The findings of this research include: 1) the frequency of errors; 2) sources of errors; and 3) strategies to overcome the difficulties in writing discussion text.

1. Errors in this study are classified based on surface strategy which consists of omission, addition, misformation, and misordering as stated by Dulay, Burt, and Krashen (1982: 150-162). Omission errors are categorized by the absence of an item that must appear in 
well-formed utterance. Addition errors are the presence of an item that must not appear in well-formed utterance. Misformation errors are type of errors that is characterized by the use of incorrect morpheme or structure.
Misordering errors are characterized by the incorrect placement of a morpheme of group of morphemes in an utterance. Table 1 shows the number of errors and the percentage of errors in writing discussion text.

Table 1 Category of Errors

\begin{tabular}{ccc}
\hline No. $\begin{array}{c}\text { Category of } \\
\text { Errors }\end{array}$ & $\begin{array}{c}\text { Number of } \\
\text { Errors }\end{array}$ & $\begin{array}{c}\text { Percentage } \\
(\%)\end{array}$ \\
\hline 1. Omission & 220 & 36.48 \\
2. Addition & 69 & 11.44 \\
3. Misformation & 121 & 20.06 \\
4. Misordering & 193 & 32.01 \\
Total & 603 & 100 \\
\hline
\end{tabular}

The highest error is omission error (220 errors of 603 total errors or $36.48 \%$ ). The second error is misordering error (193 errors of 603 total errors or $32.01 \%)$. It is followed by misformation error (121 errors of 603 total errors or $20.06 \%$ ). The last is addition errors (69 errors of 603 total errors or $11.44 \%$ ). Each of errors will be classified in the following section:

a. Omission errors can be divided into
10 subtypes, including a) omission of article; b) omission of verb; c) omission of auxiliary (to be); d) omission of letter; e) omission of preposition; f) omission of punctuation; g) omission of subject sentence; h) omission of conjunction; i) omission of regularization; and $\mathrm{j}$ ) omission of plural. The result of the study can be seen in table 2 .

Table 2. Distribution Omission Errors

\begin{tabular}{llcc}
\hline No. & \multicolumn{1}{c}{ Sub-type of Errors } & Number of Errors & Percentage (\%) \\
\hline 1. & Omission of article & 1 & 0.17 \\
2. & Omission of auxiliary (to be) & 78 & 12.93 \\
3. & Omission of letter & 25 & 4.15 \\
4. & Omission of verb & 7 & 1.16 \\
5. & Omission of preposition & 10 & 1.66 \\
6. & Omission of punctuation & 23 & 3.81 \\
7. & Omission of subject sentence & 6 & 0.99 \\
8. & Omission of conjunction & 1 & 0.17 \\
9. & Omission of regularization & 6 & 0.99 \\
10. & Omission of plural & 34 & 5.64 \\
\hline \multicolumn{4}{c}{ Total } \\
\hline
\end{tabular}

See the following example: 
Table 3 Example of Omission Error

\begin{tabular}{|c|c|}
\hline Subtypes of Omission Error & Example \\
\hline Omission of Article & $\begin{array}{l}\text { University *is place where students who want continue their } \\
\text { studied more. (SA14E1) }\end{array}$ \\
\hline Omission of Auxiliary & $\begin{array}{l}\text { But several *people not to agree with continue university who } \\
\text { usually university possible option for to get the better job. } \\
\text { (SA2E6) }\end{array}$ \\
\hline Omission of Letter & $\begin{array}{l}\text { We *shoud continue or get job directly it baseds on our } \\
\text { personality. (SA25E8) }\end{array}$ \\
\hline Omission of Verb & $\begin{array}{l}\text { *But if school continue better, because having experience and } \\
\text { knowladge for future. (SA7E6) }\end{array}$ \\
\hline Omission of Preposition & University *is one fault option for to get better job. (SA2E1) \\
\hline Omission of Punctuation & $\begin{array}{l}\text { *However wrong when we hang out with our friend would be } \\
\text { difficult to continue college and be able to quit college. (SA21E8) }\end{array}$ \\
\hline Omission of Subject Sentence & $\begin{array}{l}\text { *Not wrong if we want to increase knowledge to our future. } \\
\text { (SA8E12) }\end{array}$ \\
\hline Omission of conjunction & $\begin{array}{l}\text { Students who decide to continue their school to university often } \\
\text { think that with university lecture they can get more knowledge *go } \\
\text { in certain direction in their sector. (SA3E4) }\end{array}$ \\
\hline Omission of Regularization & $\begin{array}{l}\text { Student *after confused to continue their studies or they choose to } \\
\text { get job (SA5E2) }\end{array}$ \\
\hline Omission of Plural & $\begin{array}{l}\text { *Many student still thought their destiny later pass university } \\
\text { should can get proper work or just became unemployed. (SA20E1) }\end{array}$ \\
\hline
\end{tabular}

b. Addition errors can be divided into five subtypes: a) addition of article; b) addition of preposition; c) addition of auxiliary (to be); d)

addition of letter; and e) addition of word. The result of the study of addition errors can be seen in table 4.

Table 4 Distribution of Addition Errors

\begin{tabular}{llcc}
\hline No. & \multicolumn{1}{c}{ Sub-type of Errors } & Number of Errors & Percentage (\%) \\
\hline 1. & Addition of Article & 3 & 0.49 \\
2. & Addition of Preposition & 45 & 7.46 \\
3. & Addition of Letter & 8 & 1.33 \\
4. & Addition of Auxiliary (to be) & 7 & 1.16 \\
5. & Addition of word & 5 & 0.83 \\
\hline & $\quad$ Total & 69 & 11.44 \\
\hline
\end{tabular}

It can be seen the highest error of addition is addition of preposition (45 errors of 69 total errors or $7.46 \%)$. The lowest error is addition of article (3 errors of 69 total errors or $0.49 \%)$. The example of addition errors can be seen in table 5 . c. Misformation can be divided into six subtypes: a) misformation of word choice; b) misformation of verb; c) misformation of preposition; d) misformation of letter; e) misformation of regularization; and f) misformation of auxiliary (to be). The result of the study of misformation errors can be seen in table 6. 
Table 5 Example of Addition Errors

\begin{tabular}{|c|c|}
\hline Subtypes of Addition & Example \\
\hline Addition of Article & $\begin{array}{l}\text { So it doesn"t guarantee that *the graduated student from university can get } \\
\text { job early. (SA25E6) }\end{array}$ \\
\hline $\begin{array}{l}\text { Addition } \\
\text { Preposition }\end{array}$ & $\begin{array}{l}\text { *Being in high school is about preparing yourself for the real word and to } \\
\text { make sure you are ready to make the decisions that will be necessary later } \\
\text { of our life. (SA19E1) }\end{array}$ \\
\hline Addition of Letter & And university doesn"t *gruarantee its students to get job. (SA11E13) \\
\hline Addition of Auxiliary & $\begin{array}{l}\text { Remain if going to school *is just a waste of money and time *are better of } \\
\text { working owne. (SA1E3) }\end{array}$ \\
\hline Addition of Word & $\begin{array}{l}\text { If continue lecture we could chance for perceive lecture and lecture can } * d o \\
\text { increase quality employment. (SA16E21) }\end{array}$ \\
\hline
\end{tabular}

Table 6 Distribution of Misformation Errors

\begin{tabular}{|c|c|c|c|}
\hline No & Sub-type of Errors & Number of Errors & Percentage (\%) \\
\hline 1. & Misformation of Word Choice & 21 & 2.98 \\
\hline 2. & Misformation of Verb & 50 & 8.28 \\
\hline 3. & Misformation of Preposition & 15 & 2.48 \\
\hline 4. & Misformation of Letter & 15 & 2.48 \\
\hline 5. & Misformation of Regularization & 5 & 0.82 \\
\hline 6. & Misformation of Auxiliary (to be) & 8 & 1.33 \\
\hline & Total & 121 & 20.06 \\
\hline
\end{tabular}

Table 6 shows that the highest misformation error is misformation of verb (50 errors of 121 total errors or $8.28 \%$ ). The lowest is misformation of regularization (5 errors of 121 total errors or $0.82 \%$ ). The example of misformation errors can be seen in table 7 .

Table 7 Example of Misformation Errors

\begin{tabular}{l|l}
\hline \multicolumn{1}{c|}{$\begin{array}{c}\text { Subtypes of Misformation } \\
\text { Errors }\end{array}$} & \multicolumn{1}{c}{ Example } \\
\hline $\begin{array}{l}\text { Misformation of Word } \\
\text { Choice }\end{array}$ & $\begin{array}{l}\text { Before the students *passed away from high school they already think } \\
\text { about continuity their school. (SA3E1) }\end{array}$ \\
\hline Misformation of Verb & $\begin{array}{l}\text { We also *got a good job because it fits with what we have done in } \\
\text { college with decent we can achieve the desired goal. (SA1E6) }\end{array}$ \\
\hline Misformation of Preposition & $\begin{array}{l}\text { *In the other hand by continueing our study to university, it can spend } \\
\text { much money because we know that the school fee at university is too } \\
\text { high. (SA25E4) }\end{array}$ \\
\hline Misformation of Letter & $\begin{array}{l}\text { Many people after *gradution SMA also not go on to *colloge is } \\
\text { expensive and many people are more concerned with work than into } \\
\text { college does not guarantee employees who become unemployed. } \\
\text { (SA9E15) }\end{array}$ \\
\hline $\begin{array}{l}\text { Misformation } \\
\text { Regularization }\end{array}$ & $\begin{array}{l}\text { For example, if you continue to university you can get more } \\
\text { knowledge and *skill, } \text { Beside you to get a better job. (SA26E4) }\end{array}$ \\
\hline Misformation of Auxiliary & $\begin{array}{l}* \text { I'm not agree, because continue to university dispoce of expense } \\
\text { and time only. (SA31E8) }\end{array}$ \\
\hline
\end{tabular}

d. Misordering errors consist of eight subtypes: a) misordering of auxiliary ( to be); b) misordering of verb; c) misordering of word choice; d) misordering of word order; e) misordering of spelling; f) 
misordering of possessive pronoun;

The result of the study of g) misordering of conjunction; and misordering errors can be seen in

h) misordering of capitalization. table 8 .

Table 8 Distribution of Misordering Errors

\begin{tabular}{clcc}
\hline No. & \multicolumn{1}{c}{ Sub-type of Errors } & Number of Errors & Percentage (\%) \\
\hline 1. & Misordering of Auxiliary (to be) & 7 & 1.16 \\
2. & Misordering of Verb & 60 & 9.95 \\
3. & Misdering of Word Choice & 42 & 6.96 \\
4. & Misordering of Word Order & 7 & 1.16 \\
5. & Misordering of Spelling & 42 & 6.96 \\
6. & Misordering of Possesive Pronoun & 7 & 1.16 \\
7. & Misordering of Conjunction & 20 & 3.32 \\
8. & Misordering of Capitalization & 8 & 1.33 \\
\hline & Total & 193 & 32.01 \\
\hline
\end{tabular}

Table 8 shows that the highest error of misordering error is misordering of verb (60 errors of 193 total errors or $9.95 \%)$. The lowest error is Misordering of auxiliary, misordering of word order, and misordering of possessive pronoun (each of them is 7 errors of 193 total errorsor $1.16 \%$ ). The example of misordering errors can be seen in table 9 .

Table 9 Example of Misordering Error

\begin{tabular}{|c|c|}
\hline Subtypes of Misordering & Example \\
\hline Misordeing of Auxiliary & $\begin{array}{l}\text { *Various university this time was a lot of in anywhere place. } \\
\text { (SA22E1) }\end{array}$ \\
\hline Misordering of Verb & $\begin{array}{l}\text { We also *got a good job because it fits with what we have done in } \\
\text { college with decent we can achieve the desired goals. (SA1E6) }\end{array}$ \\
\hline Misordering of Word Choice & $\begin{array}{l}\text { Many people *select to continue their student to university, because } \\
\text { they though that simple to get the job and it can at better education. } \\
\text { (SA10E1) }\end{array}$ \\
\hline Misordering of Word Order & $\begin{array}{l}\text { School continue to support the *future better and more valued } \\
\text { people. (SA1E1) }\end{array}$ \\
\hline Misordering of Spelling & $\begin{array}{l}\text { With continue to university to get more } * \text { knoledge and skill, to get a } \\
\text { better job. (SA13E20) }\end{array}$ \\
\hline $\begin{array}{l}\text { Misordering of Possesive } \\
\text { Pronoun }\end{array}$ & $\begin{array}{l}\text { With we continue school we can get experience more and knoladge } \\
\text { benefit for *we. (SA17E6) }\end{array}$ \\
\hline Misordering of Conjunction & $\begin{array}{l}\text { * But several people not to agree with continue university who } \\
\text { usually university possible option for to get the better job. (SA2E6) }\end{array}$ \\
\hline Misordering of Capitalization & $\begin{array}{l}\text { Many student pass from *Senior High School than continue to } \\
\text { university. (SA15E1) }\end{array}$ \\
\hline
\end{tabular}

2. According to the data, there are three sources of errors that involved in students errors: interlingual transfer, intralingual transfer, and communication strategies. Table 6 shows the percentage of each type of source errors involved in students ${ }^{\text {ee }}$ errors. 
Table 10. Percentage of Source of Errors

\begin{tabular}{|c|c|c|}
\hline No. $\quad$ Type of Source of Errors & Number of Source of Errors & Percentage (\%) \\
\hline 1. Interlingual Transfer & 113 & 28.68 \\
\hline 2. Intralingual Transfer & 224 & 56.85 \\
\hline 3. Communication Strategies & 57 & 14.46 \\
\hline Total & 394 & 100 \\
\hline
\end{tabular}

Table 10 showed that the highest source of error is intralingual transfer (224 errors of 394 total errors or $56.85 \%$ ). The lowest is communication strategies (57 errors of 394 total errors or $14.46 \%$ ). From the result of data analysis, it can be found that cause students $^{\text {ee }}$ errors in writing discussion text can be explained as follows:

a. According to Littlewood (1998: 22-

23) stated errors due to rules from mother tongue are called interlingual transfer. It is because the different system between Indonesian and English. There is 113 errors or $28.68 \%$ of all errors included into this source. There are three categories of errors caused by interlingual transfer made by the students. It can be seen in table 11 .

Table 11 Example of Interlingual Transfer

\begin{tabular}{ll}
\hline \multicolumn{1}{c}{ Categories of Errors } & \multicolumn{1}{c}{ Errors } \\
\hline Morphosyntactic & $\begin{array}{l}* \text { But many students not continue to university because many *problem. } \\
\text { Category }\end{array}$ \\
Lexical Syntactic & $\begin{array}{l}\text { *Like to buy a home to parents and raise the Haji of parents with all that } \\
\text { we could have our parents happy. (SA1E8) }\end{array}$ \\
Category & *Better if you intend to continue school occupied and if it does not go to \\
Lexical Semantic & *school work as hard as possible. (SA1E19) \\
Category & \\
\hline
\end{tabular}

b. Intralingual transfer can be divided into four subtypes proposed by Richards (1984:6): a) overgeneralization; b) ignorance of rule restriction; c) incomplete application of rule; and d) semantic. Table 12 shows the percentage of subtype ses source of errors of intralingual transfer.

Table 12. Subtypes Source of Errors of Intralingual Transfer

\begin{tabular}{clcc}
\hline No. & Subtypes of Source of Errors & $\begin{array}{c}\text { Number of Source of } \\
\text { Errors }\end{array}$ & $\begin{array}{c}\text { Percentage } \\
(\boldsymbol{\%})\end{array}$ \\
\hline 1. & Overgeneralization & 13 & 3.30 \\
2. & Ignorance of Rule restriction & 60 & 15.23 \\
3. & Incomplete Application of Rule & 124 & 31.47 \\
4. & Semantic & 27 & 5.33 \\
\hline \multicolumn{2}{c}{ Total } & 224 & 56.85 \\
\hline
\end{tabular}


Table 12 shows the highest source of errors of intralingual transfer is incomplete application of rule (124 errors of 224 total errors or $31.47 \%)$. The lowest is overgeneralization (13 errors of 224 total errors or $3.30 \%$ ). The example of intralingual transfer can be seen in table 13

Table 13. Exxample of Intralingual Transfer

\begin{tabular}{|c|c|}
\hline $\begin{array}{l}\text { Subtypes of Source of } \\
\text { Errors }\end{array}$ & Example \\
\hline Overgeneralization & $\begin{array}{l}\text { *I am disagree, because continue to university *to get wasting so } \\
\text { much money.(SA13E15) }\end{array}$ \\
\hline $\begin{array}{l}\text { Ignorance of Rule } \\
\text { Restriction }\end{array}$ & $\begin{array}{l}\text { They *will wasting so much money for cost of university lecture, and } \\
\text { *they not yet to get work after pass education. (SA8E9) }\end{array}$ \\
\hline $\begin{array}{l}\text { Incomplete Application of } \\
\text { Rule }\end{array}$ & $\begin{array}{l}\text { *But several people not to agree with continue university who usually } \\
\text { university possible option for to get the better job. (SA2E6) }\end{array}$ \\
\hline Semantic & $\begin{array}{l}\text { *Remain if going to school is just a waste of money and time are better } \\
\text { of working *owne. (SA1E3) }\end{array}$ \\
\hline
\end{tabular}

$c$. The third result of source of errors is communication strategies (57 errors of 394 total errors or 14.46\%). According to Brown (1994: 178) a communication strategy is the conscious employment of verbal or nonverbal mechanism for communicating an idea when precise linguistics forms are for some reasons not readily available to the learner at a point in communication. See the following example: "*people college in ground society will more be respected. Because they more education than people in village. (SA6E14)"

3. From the data analysis, there are twelve difficulties and fifteen strategies to overcome the difficulties in writing discussion text. The strategies to overcome the difficulties are being careful when using plural or singular noun in English; understanding the differences of Indonesian and English grammar; not translating Indonesian sentences pattern to English because they have completely different grammar or translating word for word only; using monolingual dictionary to check every word; and always checking vocabulary whether the word has spelled correctly or not. As the result, checking our own writing before submitting is very important. Table 14 shows the strategies to overcome the difficulties in writing discussion text.

Table 14 shows there are fifteen strategies to solve the students ${ }^{\text {ee }}$ difficulties in writing discussion text. The student should make a text as clear as possible, without any confusion or mistakes, so that whoever reads it will understand. As the result, checking our own writing before submitting is very important.

The finding shows that the most students $^{\text {ee }}$ error is omission. The students omitted necessary item in their own text. This result similar to Dulay, Burt, and Krashen (1982: 105) language learner omit grammatical morphemes much more frequently than content words. The second error is misordering. The third is misformation. It is happened when the students did not know the correct verb. The last is addition. The students always added 
Table 14 Strategies to Overcome the Difficulties

\begin{tabular}{lll}
\hline No. Source of Errors & \multicolumn{1}{c}{ Difficulties } \\
\hline 1. $\begin{array}{l}\text { Interlingual } \\
\text { transfer }\end{array}$ & $\begin{array}{l}\text { Recognizing plural and } \\
\text { singular }\end{array}$ \\
& $\begin{array}{l}\text { Differentiating Indonesian } \\
\text { structure and English } \\
\text { structure }\end{array}$ \\
& $\begin{array}{l}\text { Finding the right word in } \\
\text { target language to express } \\
\text { the idea }\end{array}$ \\
& \\
& \\
Using word in target \\
mistaking in collocation.
\end{tabular}

2. Intralingual transfer : Overgeneralization

Ignorance of rule restriction
Incomplete application of rules
Strategies to Overcome (Recommendation for the student)

Being careful when using plural or singular noun in English. In Indonesian, this thing does not much matter vice versa in English, every countable noun should be treated as either singular or plural.

a. Understanding the differences of Indonesian and English grammar.

b. Not translating Indonesian sentence pattern to English because they have completely different grammar or translating word for word only.

c. Not translating based on the dictionary only.

a. Besides, using bilingual dictionary, the students use monolingual dictionaries such as: Oxford dictionary, Cambridge Dictionary for Advanced Learner, Encarta Dictionary to check.

b. Watching film or news in English to increase vocabulary.

Interacting more with English context and material to increase awareness on some collocation problems

Making list of countable and uncountable noun and memorize all of them.

Recognizing countable and uncountable noun in English

Recognizing some exceptional cases in language such as prepositions, adverb, etc.

Understanding limitation to certain rule to be applied Understanding each function of tenses and when to apply them Understanding each rule and its function thoroughly. Students often make errors in this case because they use random rule because they feel that it is appropriate or without full understanding in it.

Understanding each type of sentences (statement, interrogative, negative) and also how to make compound or complex sentences. In this research, many students apply half of the rule and mix it with others.

Recognizing correct Always checking vocabulary whether the word spelling for each English word.
Checking every word in monolingual dictionary.

Interacting more with authentic material.

Understanding each function of rules and keep practicing to apply them.

In discussion text, the information uses the simple present tense.

Rules are rules. It is restricted to some conditions. Student should not use random rule just because they feel that is correct but student should understand why they employ certain rule to certain context.

Rule should be completely in appropriate order. has spelled correctly or not. 


\begin{tabular}{|c|c|c|c|}
\hline & & $\begin{array}{l}\text { Choosing } \\
\text { preposition for cortain } \\
\text { verb. }\end{array}$ & $\begin{array}{l}\text { Certain set of verb and preposition may result in } \\
\text { a completely different meaning from the original } \\
\text { verb. }\end{array}$ \\
\hline \multirow[t]{3}{*}{3.} & $\begin{array}{l}\text { Communication } \\
\text { Strategies }\end{array}$ & $\begin{array}{l}\text { Choosing correct word to } \\
\text { express meaning }\end{array}$ & $\begin{array}{l}\text { Some students mistake certain word for another } \\
\text { they heard that they were pronounced similarly. } \\
\text { Student should also increase their reading habit } \\
\text { so that their vocabulary increases. Student } \\
\text { should check meaning of word in the dictionary. }\end{array}$ \\
\hline & & $\begin{array}{l}\text { Using appropriate series of } \\
\text { words to convey meaning } \\
\text { that one could not find in } \\
\text { target language. }\end{array}$ & $\begin{array}{l}\text { Doing communication strategies to communicate } \\
\text { ideas that have no form in target language } \\
\text { sometimes is inevitable. }\end{array}$ \\
\hline & & $\begin{array}{l}\text { Using appropriate } \\
\text { collocation in target } \\
\text { language. }\end{array}$ & $\begin{array}{l}\text { However, composing new term in target } \\
\text { language should obey the grammar in target } \\
\text { language so that writer of the target language } \\
\text { can grasp the meaning. }\end{array}$ \\
\hline
\end{tabular}

Moreover, the student ${ }^{\text {e' }} \mathrm{s}$ errors are caused by three sources. The highest is intralingual transfer. Intralingual transfer often imilar to those produced by the child in the mother tongue and suggest that the second language learner is employing similar strategies (Littlewood, 1998: 23). The highest error in intralingual transfer is incomplete application of rules. This error involves failure to fully develop structure. It is followed by ignorance of rule restriction. This error happens when the students failed to observe the restriction of existing structure.

The second is interlingual transfer. This error happened since the most of the students still tried to translate meaning from their native language (Indonesian) to target language (English) which sometimes do not work. Brown (1994: 173) stated the beginning of learning second language is characterized by good deal of interlingual transfer from the native languge or interference. The third source of error is communication strategies. It is supported by Brown (1994:78) a communication strategy is the conscious employment of verbal or nonverbal mechanism for communicating an idea when precise linguistics forms are some reasons not readily available to the learner at a point in communication.
From table 14, it can be seen that there are several strategies to overcome the students $^{\text {ee }}$ difficulties in writing discussion text. The students should be careful when using plural or singular noun in English. Besides, students should check every word in monolingual dictionary (Oxford dictionary or Encarta dictionary). Moreover, students should check vocabulary whether the word has spelled correctly or not. From the data, it can be seen that some students made errors in spelling. They did not check the correct spelling in the dictionary.

In conclusion, it is clear that students $^{\text {ee }}$ errors in writing discussion text are generally caused by the carelessness of the students, their lack interaction in target language context and willingness to learn by their own when they outside the classroom. The different system of both target language (English) and source language (mother tongue) is the main factor of the existence of errors in their construction a discussion text. Many students generated the system of English with their native language, Indonesian. The students were used the Indonesian to construct English sentences in their discussion text writing. 


\section{CONCLUSION AND SUGGESTIONS}

The data collection and analysis have been presented in the previous chapter in which findings are obtained. It can be concluded that there were a number of errors made by students in writing discussion text. The types of errors made by the students in discussion writing are based on surface strategies which are classified into omission, addition, misformation, and misordering. The finding of this research shows that there were a number of errors in writing discussion text.

There are $148(19.7 \%)$ mistakes and 603 (80.3\%) errors from 31 discussion text. In surface strategies, it is classified into four subtypes; omission, addition, misformation, and misordering. The total errors of each kind are omission errors consist of 220 errors (36.48\%), addition 69 errors (11.44\%), misformation 121 errors (20.06\%), and misordering 193 errors $(32.01 \%)$.

Furthermore, there are some sources of errors that caused students committing errors in writing discussion text. The first source of errors is interlingual transfer which is caused by the interference of their mother tongue with 113 errors or $28.68 \%$ of all errors. The second is intralingual transfer which is a negative transfer within the target language (English) with 224 errors or $56.85 \%$ of all errors, which can be specified as follows: $13(3.30 \%)$ errors in overgeneralization, $60 \quad(15.23 \%)$ of ignorance of rule restriction, 124 (31.47\%) of incomplete application of rule, and 27 $(5.33 \%)$ of semantic errors. The third source of errors is communicative strategies in which students consciously employed certain mechanism for communicative an idea when precise linguistics forms are for some reasons not readily available to the learner at the point of communication. This source of errors occurs to 57 errors or $14.46 \%$ of all errors.

The findings of this study are expected give some benefits in language study, especially English and English teaching. In teaching writing, the teacher should pay attention to all errors made by the students, to reduce students ,errors that are related to the causes of error, the teacher should give clear explanation about English structure and grammar that can be easily understood by the students. Besides, teacher should motivate students to be aware on language rules, increase their interaction to target language context, and use monolingual dictionary. For the students, they should be aware of their errors and try to overcome their problem in studying English.

\section{BIBLIOGRAPHY}

Brown, H. Douglas. (1994). Teaching By Principles: An Interactive Approach to Language Pedagogy. New Jersey: Prentice Hall.

Brown, H. Douglas. (2000). Principles of Language Learning and Teaching. New Jersey: Prentice Hall Regents.

Brown, H. Douglas. (2004). Language Assessment: Principles and Classroom Practices. New York: Longman.

Darus, Saadiyah. (2009). Error Analysis of the Written English Essays of Secondary School Students in Malaysia: A case Study. European Journal of Social Sciences Volume 8, Number 3 Retrieved from: http://www.researchgate.net/public ation/235772401

_Error_analysis_of_the_written_en 
glish_essays_of_secondary_school _students_in_Malaysia_A_case_st udy/file/9c9605153fc39a7418.pdf

Dulay, H., Burt, M., and Krashen,S. (1982). Language Two. Oxford: Oxford University Press.

Ellis, Rod. (1994). The Study of Second Language Acquisition. Oxford: Oxford University Press

Endorgan, Vacide. (2005). Contribution of Error Analysis to Foreign Language Teaching. Mersin University journal of the faculty of education. 1(2), 261-270. Retrieved from: http://research.iaun.ac.ir/pd/shafiee nahrkhalaji/pdfs/HomeWork_5173 .

Fraenkel and Wallen, Jack R. (2004). How to Design and Evaluate Research in Education. New York: Longman Inc.

Husain, Zahoor. (2013). An Error Analysis of L2 Writing at Higher Secondary Level in Multan, Pakistan. Retrieved from: http://journalarchieves30.webs.com/828844.pdf

Littlewood, William. (1998). Foreign and Second Language Learning. Cambridge: Cambridge University Press.

Richards, Jack C. (1997). Error Analysis: Perspectives on Second Language Acquisition. New York: Longman.

Richards, Jack C. \& Renandya, Willy A. (2002). Methodology in Language Teaching an Anthology of Current Practice. New York: Cambridge University Press.
Zawahreh, Dr.Firas Ali Suleiman.(2012). Applied Error Analysis of Written Production of English Essays of Tenth Grade Students I Ajloun Schools,Jordan. Retrieved from: http://www.macrothink.org/journal /index.php/ijld/article/download/16 80/1391. 